\title{
Myśl historiozoficzna Augusta hr. Cieszkowskiego Stulecie niebywałych przemian polityczno-społecznych impulsem interdyscyplinarnych zainteresowań autora Prolegomeny do historiozofii ${ }^{1}$
}

Modne do niedawna rozważanie roli jednostki w historii $\mathrm{w}$ ramach redagowanych opracowań naukowych wybitnych myślicieli i uczonych, a także wybitnych przywódców państw i działaczy politycznych itd., okazuje się współcześnie już badawczo niewystarczające, selektywne i pozorne w swej dogłębności, a nawet wręcz mylne czy wykrzywiające podjętą próbę odwzorowania $\mathrm{w}$ tejże badawczej refleksji inteligibilne odbicie spełnienia się $\mathrm{w}$ jestestwie w glorii życia tegoż człowieczego podmiotu poprzez twórczy namysł i czyn intelektualny, jaki na sposób materialny pozostaje udziałem każdej oikoumene narodu bądź państwowości jako kulturowe dziedzictwo. Może nam się wydawać, że to właśnie wyłącznie wybitne jednostki zmieniają bądź odmieniają bieg dziejów. Lecz na przykładzie Augusta hr. Cieszkowskiego przychodzi nam raz jeszcze, pełniej badawczo rozpoznać, że bieg dziejów nie jest ciągiem logicznym jakiegoś rozwijanego intelektualizmu czy wręcz determinizmu, który za każdym razem należałoby przełamywać. Jako egzystencjalne osoby przychodzi nam się spełniać w jestestwie w glorii życia, głęboko tkwiąc w żywej tkance narodu (społeczeństwa bądź kulturowej wspólnoty), za każdym razem podejmując indywiduowo i zarazem wspólnotowo jako wolne osoby i podmioty próbę poznawczego namysłu nad dosięgającą nas rzeczywistością i naszym tkwieniem w niej, przekonując się (intuicyjnie bądź

\footnotetext{
${ }^{1}$ Niniejsze badawcze rozważanie zostało zredagowane na podstawie przygotowanego pod tym samym tytułem wystąpienia na V spotkaniu z cyklu Popołudnie z dokumentem, pt.: August Cieszkowski - w 200 rocznicę urodzin, organizowanego przez Archiwum Państwowe w Poznaniu i Muzeum Historii Miasta Poznania wraz z Uniwersytetem Przyrodniczym w Poznaniu w Muzeum Historii Miasta Poznania - Stary Rynek 1 [Ratusz].
} 
świadomie), że każdy błąd w poznaniu bezwzględnie okaże się czy wręcz okazuje moralnym złem w działaniu.

Biografia Augusta Cieszkowskiego pozostaje powszechnie znaną - zwłaszcza wszystkim zainteresowanym XIX stuleciem dziejów polskiego narodu. I chociaż zostały opracowane jego poglądy filozoficzne, społeczne i polityczne, gospodarcze i ekonomiczne, dopełnione opracowaniem jego działalności naukowej i politycznej, to nie wydaje się, aby pełna biografia naukowa, na którą wciąż jeszcze oczekujemy jako środowiska naukowe i badawcze, zdołała wyczerpać spojrzenie na życiowe, egzystencjalne opus Augusta hr. Cieszkowskiego ${ }^{2}$.

Podjęte w poniższym rozważaniu badawcze spojrzenie na życiowy czyn i nierozerwalnie sprzęgniętą z nim twórczość pisarską i zwłaszcza badawczą Cieszkowskiego stanowi próbę rozpoznania twórczego spełnienia się w jestestwie w glorii życia, wtopionego w wydarzanie się polskiego oikoumene w ścisłej interakcji z dziedzictwem kulturowym Rzeczypospolitej jako niepowtarzalnej wspólnoty cywilizacyjnej. W pierwszym etapie tychże badawczych refleksji podejmiemy próbę spojrzenia na kulturowe dziedzictwo Rzeczypospolitej i sytuację duchowej epoki dziewiętnastowiecznej, w której przyszło spełniać się twórczo autorowi Ojcze Nasz; natomiast w drugim etapie rozważań pozwolimy sobie jedynie na przykładowe ukazanie ścisłego związku pomiędzy kulturowością narodu Rzeczypospolitej i dziejami narodu polskiego a tkwieniem Cieszkowskiego w tymże kulturowym dziedzictwie polskiej oikoumene i podjętą twórczością jako jednej z płaszczyzn jego spełnienia się w jestestwie $\mathrm{w}$ glorii życia.

\section{Interakcja kulturowego dziedzictwa Rzeczypospolitej i sytuacji duchowej epoki dziewiętnastowiecznej perspektywą rozumienia opus twórczego Augusta hr. Cieszkowskiego}

Namyślając się nad wyborem najlepszego sposobu i zarazem najbardziej całościowej perspektywy uchwycenia opus naukowego Augusta hr. Cieszkowskiego - opus, pozostającego bezsprzecznie materialnością jego życiowego spełniania się $\mathrm{w}$ jestestwie, nie jesteśmy wolni od uświadomienia sobie imperatywu, że takąż badawczą refleksję należałoby rozpocząć bądź, lepiej, osadzić od nawiązania do realiów europejskiej nowożytności. Ale zanim to stanie się naszym udziałem, pozwolimy sobie przywołać interesują-

\footnotetext{
2 Por. K. Wojnowski, Wstęp. August hr. Cieszkowski, [w:] A. Cieszkowski, Prolegomena do historiozofii, Poznań 2007, s. 11.
} 
ce w swej treści zdanie Jana Baudouin de Courtenay ${ }^{3}$ (1845-1929) - wybitnego polskiego slawisty i językoznawcy, iż Rzeczypospolita nie odrodziła się jako państwo w 1918 roku, aby stać się jedną z „hien imperialistycznych” jak to się okazywało naocznym w reakcji mocarstw zachodnioeuropejskich na agresję niemiecko-sowiecką na Polskę we wrześniu 1939 roku i na okupacyjne biologiczne i kulturowo-moralne unicestwianie polskiej oikoumene (resp. narodu $)^{4}$ oraz okresu powojnia (1944-1956) ${ }^{5}$, stanowiącego rezultat podziału korzyści koalicji antyniemieckiej mocarstw alianckich układem w Teheranie i Jałcie (1944), a ostatecznie w Poczdamie (1945) - aż po współczesny rozdział wpływów politycznych i gospodarczo-ekonomicznych korzyści, jaki niestety jest nieprzezwyciężalnym udziałem współczesnych zachodnioeuropejskich mocarstw unijnych i ich wykształcanych systematów społeczeństw globalnych.

Pośród licznej rzeszy pokoleń narodu Rzeczypospolitej długiego czasu zaborów, kształtujących ethos swego życia polską kulturowością i cywilizacyjnością, odrodzenie się jej w państwowości nieimperialistycznej jest także niemałą zasługą Augusta Cieszkowskiego w dziele jego życiowej aktywności i naukowej twórczości. Nie jest bowiem tak, że dzieło naukowe jako odseparowane od życia i wydarzania się społeczeństwa w jego licznych interakcjach postaw i działań człowieczych podmiotów pozostaje i zarazem jest jedynie kolejnym etapem rozwoju jakiegoś intelektualizmu. Stanowi raczej wyraz twórczego spojrzenia na rzeczywistość wydarzania się dziejów narodu w jednoczesnym konfrontowaniu się systematów państwowości i ich kulturowości wraz z podejmowaniem konkretnych przedsięwzięć życiowych przez aktywnie uczestniczących w życiu narodu myślicieli i badaczy - takich, jak m.in. Cieszkowski, na co wskazuje jego opus naukowe, zawierające oprócz dzieł historiozoficznych także prace poświęcone życiu społecznemu i gospodarczo-ekonomicznego. Wystarczy bowiem przywołać jedynie poniższe dzieła intelektualne: Du crédit et de la circulation (1839), De la pairie et de l'aristocratie (1840) bądź O romansie nowoczesnym (1846), aby pozostawać pewnym życiowego horyzontu badawczych zainteresowań hr. Cieszkowskiego.

${ }^{3}$ Jan Ignacy Niecisław Baudouin de Courtenay - najwybitniejszy polski językoznawca, umieszczany wśród największych lingwistów świata; profesor uniwersytetów w Petersburgu, Kazaniu, Dorpacie, Krakowie i Warszawie.

4 Zob. R. Ingarden, Ksiażeczka o człowieku, Kraków 1972, s. 34.

${ }^{5}$ Przywołany terror władzy z lat 1945-1956, czyli zarówno eksterminacja Polaków i fizyczna likwidacja tych, których uznano za przeciwników nowych jej form (podległości komunistycznemu caratowi Kremla), jak i zniewalanie narodu przez nieustanne stwarzanie poczucia zagrożenia, które bezwzględnie należy postrzegać w kategoriach martyrologii polskiej, stanowi zjawisko o wiele bardziej skomplikowane niż męczeństwo, jakie stało się udziałem Polaków doby drugiej wojny światowej - w tym także zapomniane wydarzenie (tzw.) rzezi Woli z 5 sierpnia 1944 roku, znane wąskiemu kręgowi pamiętających (por. Z. Taranienko, Nasze Termopile, Warszawa 1993, s. 58-59; P. Gursztyn, Rzeź Woli. Zbrodnia nierozliczona, Warszawa 2014). 
Niezaprzeczalnie jest to całkiem, a nawet wręcz radykalnie odmienna postawa intelektualna - chociażby od myślicieli niemieckich tej samej doby stulecia niebywałych przemian polityczno-społecznych, w której spełniał się w człowieczym jestestwie autor Prolegomeny do historiozofii (1833).

Co zatem takiego istotnie ważnego wydarzyło się w epoce Reformacji i Humanizmu? Co miało aż tak głębokie reperkusje w skutkach, że naznaczyło epokę życiowego spełniania się Augusta Cieszkowskiego znamieniem niebywałych przemian? Oczywiście, nie mamy wyłącznie na myśli niepowtarzalności polskiej kulturowości wydarzającego się w następstwie kolejnych pokolen oikoumene Rzeczypospolitej, która już wówczas, czyli w XVI stuleciu, stanowiła dla myślicieli i pisarzy politycznych dawnego frankijskiego Zachodu nieprzełamywalną i nierozwiązywalną łamigówkę. Nie znajdywali bowiem adekwatnej ze znanych sobie kategorii, kiedy podejmowali próbę określenia systematu państwowego Rzeczypospolitej Obojga Narodu według znanych sobie kategorii i przyporządkowań. Dopiero od doniosłych badań Feliksa Konecznego (1862-1849) - polskiego historyka i historiozofa, dogłębnie zdajemy sobie sprawę z tego, że nieprzezwyciężalną trudność sprawiało im rozstrzygnięcie, czy państwo polskie jest monarchią temperata czy też governo popolare; czy jest arystokracją, królestwem czy też republiką? Również nie mamy na myśli odmienności Korony polskiej, jaka ukazała się w samych podwalinach $\mathrm{w}$ konfrontacji świata germańskiego i świata słowiańskiego w bitwie pod Grunwaldem - rozstrzygniętej militarnie, lecz na ówczesnym etapie zakończonej rozstrzygnięciem ówczesnego parlamentu europejskiego, jaki stanowił sobór w Konstancji w latach 1414-1418.

Lecz wręcz imperatywem pozostaje przywołanie znanych współczesnym badaczom dziejów myśli filozoficznej faktu, że wraz z upadkiem Konstantynopola i w ogóle Bizancjum w 1453 r. epoka nowożytna pozwoliła sobie nieświadomie zaszczepić nie tyle kulturę grecką (helleńską), co hellenistyczną jej wersję orientalną. Dopiero współcześnie - i to jeszcze jedynie w wąskich kręgach badaczy-specjalistów w dziedzinie - zdajemy sobie sprawę z tego nieoczekiwanego i zarazem niebywałego faktu. Nie sposób utrzymać badawczej tezy, że miał on wyłączną bądź dominującą rolę w wypaczeniu kulturowego podłoża i podwalin intelektualnych fundujących nowożytność europejską. Jednak nie można niedocenić faktu dziejowego, że cywilizacyjne zagrożenie z zewnątrz przez napierające na Bizancjum imperium osmańskie (tureckie) spowodowało jakby uwewnętrznienie bizantyńskiego systematu cywilizacyjnego i naznaczenie jego znamieniem - w różnym zakresie, co jest zrozumiałe - poszczególnych władztw i ich państwowości dotychczasowej mediewalnej Christianitas - łacińskiego Zachodu.

${ }^{6}$ Por. F. Koneczny, Polskie Logos a Ethos. Roztrzasanie o znaczeniu i celu Polski, t. I, Poznań 1921, s. 400. 
Badawczo zdajemy się wychwytywać dopiero z perspektywy czasu przesunięcia w rozłożeniu poszczególnych elementów systematu cywilizacyjnego łacińskiego Zachodu, jakie wówczas się dokonały. W pewnej mierze podpowiada nam Arystoteles interpretację zjawiska, jakiego udziałem stały się pokolenia schyłku średniowiecza i początków europejskiej nowożytność - jakby zachłyśnięte renesansem (włoskim), który z północnej Italii rozprzestrzenił się po niemal wszystkich zakątkach terytorialnej Europy, inspirując także wiele twórczych inicjatyw. I faktycznie, należy przyznać Arystotelesowi słuszność spostrzeżenia, jakiego dokonał, że mały błąd na początku okazuje się olbrzymim (resp. wielkim) na samym końcu. Ale nakładające się na siebie i wzajemnie się warunkujące "dzieło" ideologicznych przekonań - tak, niestety, należy je współcześnie rozpoznać - trzech reformatorów i zarazem fundatorów europejskiej nowożytności, czyli Lutra, Kartezjusza i Rousseau, wyznaczających perspektywę dla religijności, intelektualności i społecznego wymiaru dążeń człowieczych oikoumene - rozwarły przestrzeń wypaczania wiary [chrześcijańskiej], spaczenia rozumu i spaczania się uczuć 7 . Na przekór oczekiwaniom ówczesnych epoki Reformacji i także nas współczesnych Luter nie wyzwolił osoby ludzkiej, ale ją wykoleił ${ }^{8}$. Kartezjusz - twórca słynnego nowożytnego przekonania: cogito ergo sum ${ }^{9}$ - nie zdołał ufundować niepodważalnej metody poznawczej, ale nie rozróżniając mechanizmu myślenia od jego wytworu inteligibilnego w istocie „pomieszał” treści (człowieczego) myślenia z samym myśleniem. Ostatni zaś z reformatorów - autor Rozprawy o pochodzeniu i podstawach nierówności między ludźmi (1755), sytuując się w perspektywie ideologicznych założeń późnych scholastyków - a konkretnie: w przejętej od nich kwestii idei koniecznej samowystarczalności przyrody ${ }^{10}$ i jednocześnie sprawionym przez nich skrzywieniu myśli teologicznej pod wpływem sztywnego arystotelizmu przez utrzymywanie hipotetycznej możliwości „stanu natury czystej"11 - i całego gremium oświeceniowych myślicieli skutecznie dopro-

7 Por. J. Maritain, Trzej reformatorzy: Luter, Kartezjusz, Rousseau, tłum. K. Michalski, Warszawa 2005, s. 51n.

${ }^{8}$ Por. tamże, s. $73 \mathrm{n}$.

9 Powinno raczej ono brzmieć: „Myślę, więc nie jestem”. „Wszyscy wprawdzie jesteśmy przeświadczeni, że aby istniało myślenie, musi istnieć myślący - ale skoro zaczęło się powątpiewać we wszystko, nawet $\mathrm{w}$ prawdy matematyczne, to i ta może budzić wątpliwość. Z kartezjańskiego punktu widzenia nie mamy żadnego prawa twierdzić, że tak jest. Cogito dowodzi więc tylko tego, że jakieś myślenie istnieje - $\mathrm{z}$ tym, że tu słowo >istnieje< oznacza jedynie, iż snują się nam w świadomości takie czy inne treści. Wniosek na egzystencję, na istnienie myślącego nie ma żadnego uzasadnienia" (J.M. Bocheński, Ku filozoficznemu myśleniu. Wprowadzenie do podstawowych pojęć filozoficznych, tłum. B. Białecki, Warszawa 1886, s. 23).

${ }^{10}$ Por. R. Spaemann, O pojęciu natury ludzkiej [tłum. Z. Krasnodębski], [w:] Człowiek w nauce wspótczesnej, Paris 1988, s. 139.

${ }^{11}$ Dopowiedzmy - wskutek przyjęcia takiego założenia zmuszeni byli uznać, że „wszelka refleksja o człowieku i jego przeznaczeniu powinna urzeczywistniać się przy przyjęciu za punkt wyjścia i stałe kryterium tego właśnie stanu" (J.I. Saranyana, J.L. Illianes, Historia teologii, tłum. 
wadził przywódców Wielkiej Rewolucji Francuskiej - zasadniczo jakobińskich - przez [w istocie błędne] zestawienie przesłanek intelektualnych do przekonania, że wystarczy uwolnić człowieka od gnębiących go warunków społecznych, aby dopełniła całej reszty wykształcenia od podstaw nowego społeczeństwa jego dobra z samej swej istoty natura [ludzka] - przekonania, które odwzorowało się $\mathrm{w}$ rewolucyjnym dziele, nie będącym jednak żywiołowym buntem mas, lecz czynem terroru wąskiego kręgu ludzi, uważanych ówcześnie za wykształconych - oświeconych utopijnym mitem o pierwotnie dobrej i całkowicie plastycznej naturze człowieka ${ }^{12}$.

Przywołujemy powyższe, pomni na najbardziej realistyczną zasadę, wyznaczającą prawidłowość człowieczej egzystencji, że każdy fałsz w poznaniu okazuje się i zarazem po prostu jest złem w działaniu, że każdy błąd nadaje złu pozór dobra, prowadząc w konsekwencjach do działań (resp. moralnych postaw, zachowań) bezcelowych i moralnie nikczemnych ${ }^{13}$. I chociaż błędy z zakresu inteligibilności, fundujące europejską nowożytność, zamieniły filozofię w pseudofilozofię, występującą w myślowej formie mitu, utopii lub ideologii, to jednak utrzymała się ona $\mathrm{w}$ dominującej roli jako inspirująca teorie polityczne i gospodarcze, moralne i prawne, estetyczne i religijne - chcąca dowolnie kreować świat człowieczych oikoumene, nie zadowalając się jej wzniosłym ideałem wyjaśniania świata na potrzeby spełnienia czy spełniania się człowieczego podmiotu $\mathrm{w}$ jestestwie w kulturowości zróżnicowanych cywilizacyjnie ludzkich oikoumene, kiedy jako „mądrość rozumu” - zaś nie jako racjonalność praktyczno-pragmatyczna - $\mathrm{w}$ bezinteresownym oglądzie rzeczywistości, kontemplacji sięgającej ostatecznych przyczyn świata osób i rzeczy dosięgała istoty swej najbardziej niezwykłej funkcji, rozpoznanej i wyznaczonej przez myślicieli staroży tnej Jonii - namysłu nad physis i rozróżnionym zeń człowieczym oikoumene.

Ale jednocześnie w kontekście rozumienia czy wręcz rozpoznania przez badaczy dziejów europejskich XIX w. jako epoki niebywałych przemian polityczno-społecznych, której duchowy klimat stał się impulsem interdyscyplinarnych zainteresowań Augusta hr. Cieszkowskiego, nie możemy nie podnieść, że „skrojona” (resp. złożona) z empiryczności - w sensie osadzenia na koncepcji prawdy empirycznej, czyli opisującej świat fizyczny - filozofia nowożytnych myślicieli „zwalczała” (resp. poddawała ideowemu unicestwieniu) wszystko to, co nie zgadzało się z empirystycznym i materialistycznym

P. Rak, Kraków 1997, s. 449). Kwestię badawczo uwydatnił Henri de Lubac (1896-1991) w jednym z wczesnych swych dzieł Surnaturel (Paris 1946).

12 Zob. D. Kubicki, "Ideologizm nowożytnej idei 'powrotu do natury' i 'czystej' natury a ponowożytne projekty nowych społeczeństw", Prace Naukowe Akademii im. Jana Długosza w Częstochowie, seria: Rocznik polsko-ukraiński, t. XVI, Częstochowa-Lwów 2014, s. 25-56.

${ }^{13}$ Por. H. Kiereś, Trzy socjalizmy. Tradycja tacińska wobec modernizmu i postmodernizmu, Lublin 2000, s. 6. 
opisem świata (resp.physis). Okazujący się jednak stuleciem nieprzewidywalnych anomalii wiek XIX odsłaniał bezwzględnie rozbieżności pomiędzy tym, co miało wyznaczać paradygmat „prawdziwego" świata, a faktycznymi realiami physis $\mathrm{z}$ wyróżniającym się $\mathrm{w}$ niej oikoumene, pokazując $\mathrm{w}$ istocie pozorność triumfu pozytywizmu i materializmu. Uwydatniał i zarazem unaoczniał nagi fakt niespójności zjawisk w sferze „wydarzania się" physis z opisem świata takim, jakim ukazywany był w mechanicystyczno-deterministycznym opisie $^{14}$. Wychwytywane anomalie $\mathrm{w}$ fizyce, a następnie kreślone geometrie nieeuklidesowe inicjowały tąpnięcie świata fizycznego - dotychczasowego bożka filozofii empirycznej nowożytności europejskiej.

Należałoby dopowiedzieć, że dezaktualizująca się koncepcja prawdy filozofii empirycznej została zastąpiona koncepcją prawdy Georga W.H. Hegla (1770-1831). Nie osadzając swego rozpoznania na logicznie zasadnym ciągu myślowych przesłanek (w uproszczeniu), autor Fenomenologii ducha (1807) wprowadził siłą swego ówczesnego wpływu (resp. sławy) koncepcje prawdy jako całości - koncepcję, wykształconą na podłożu założenia, że wiedza jest całością. Logicznym wedle takiegoż założenia wydawał się zatem sformułowany wniosek, że prawdziwa jest wyłącznie całkowita wiedza o świecie, że prawda jest zatem całością i że wszystkie inne "prawdy” (teraźniejszości bądź wycinków człowieczego życia, inteligibilnie konstruowane na bazie zmysłowo-intelektualnego poznania) są wyłącznie i aż jedynie fragmentami tejże Wielkiej Prawdy - Prawdy absolutnej ${ }^{15}$.

Podnosimy powyższe, aby zarysować kontekst duchowy epoki, w której przyszło wzrastać i tworzyć autorowi Prolegomeny do historiozofii. Ponadto konieczne wydaje się zwrócenie uwagi na inny jeszcze fakt dziejowy - zazwyczaj niezauważany. Na szczególniejszą bowiem uwagę zasługuje fakt implantacji w systemacie mediewalnej Christianitas wielu sposobów uprawiania polityki na sposób bizantyjski. Ów świat rodzącej się polityki europejskiej nowożytności opisał Nicolò Machiavelli w swym sławnym Il Principe (1532) i na baczniejszą uwagę zasługuje, że od ukazania się drukiem sławniejące w elitach władzy nowożytności europejskiej i mieszczaństwa dzieło nie zostało przełożone na język polski aż po schyłek XIX stulecia. I chociaż współcześnie badawczo rozpoznaliśmy, że ówcześnie pojawiła się w miarę skuteczna próba ideowego zjednoczenia europejskiej państw i ich elit ideologicznym (w sumie) potraktowaniem teologicznego dzieła Akwinaty jako doktryny spinającej późnośredniowieczną Christianitas, przede wszystkim i zasadniczo przed zagrożeniami z zewnątrz (imperium osmańskie, tureckie), kosztem zapoznania, że twórczość św. Tomasza z Akwinu, jako konkretny fakt historyczny,

${ }^{14}$ Zob. H. Skolimowski, Prawda a problem ludzkiej egzystencji, [w:] Poznanie a prawda, pod red. A.L. Zachariasza, Rzeszów 2009, s. 209.

${ }^{15}$ Por. tamże, s. 209. 
wyrosła ze scholastyki i powinna pozostać, jako dzieło XIII stulecia, tworem scholastycznym, oraz kosztem niewłaściwego sprzęgnięcia metafizyki tomistycznej z arystotelizmem, które ujemnie odbiło się nie tylko na samej metafizyce, ale i na scalonej z nią teologii aż po współczesność, to jednak niestety nie wychwyciliśmy i zarazem nie zostało podjęte przebadanie i zarazem zbadane, na ile w tymże okresie Renesansu i Humanizmu Il Principe przyczynił się do demoralizacji establishmentów władzy i polityki epoki w zakresie metod pozyskiwania władzy i skutecznego rządzenia, bezwzględnie rozłączając politykę od jakiejkolwiek moralności, a zwłaszcza uprawiających ją od jakiegokolwiek poczucia odpowiedzialności za czyny o wymiarze politycznym.

Przywołaliśmy powyżej stwierdzenie, że państwowość polska stanowiła niezwykle trudny do rozpoznania przez szesnastowiecznych pisarzy zachodnioeuropejskich systemat. Dopiero współcześnie wychwytujemy źródło tego rozróżniania się systematu państwowości polskiej na tle państwowości zachodnioeuropejskich. I rozumiemy, że państwowość wynikała z samej genezy społeczeństwa Rzeczypospolitej, która bezsprzecznie była i zarazem okazywała się szlachecka. Niepowtarzalnością więc na tle uorganizowań frankijskiego Zachodu było przede wszystkim to, że w Polsce szlachcic stanowił warstwę najstarszą, pierwotną - bezwarunkowo starszą od ludu wiejskiego $^{16}$. Stąd całkowicie zrozumiałe pozostają słowa, wyrażone na samym dosłownie wstępie opus historycznego Henryka Schmitta Dzieje narodu polskiego (Lwów 1863): „[...] dzieje polskie różnią się tém od innych, że są głównie dziejami narodu, a nie królów lub książąt"17.

Bezsprzecznie z tejże społeczno-biologicznej podwaliny kulturowej wynikły wszystkie niepowtarzalności polskiej cywilizacyjności i kulturowości aż po systemat państwowy i przede wszystkim zauważalne rozróżnienie, które dojrzale i w pełni wyraził przywołany Feliks Koneczny, zauważając, że podczas gdy inne narody słowiańskie poprzestawały na asymilowaniu się z kulturą zachodnią, czyli łacińską, bądź kulturą bizantyńską, pomnażając cywilizację - cywilizację śródziemnomorską, terytorialnie europejską (w uproszczeniu) i samo chrześcijaństwo (łacińskie), czego dowodem pozostaje [na przykład] kwestia slawizacji chrześcijaństwa łacińskiego i zarazem bizantyńskiego ${ }^{18}$, to jedynie Polska, naród Korony polskiej - Rzeczypospolitej,

${ }^{16}$ Feliks Koneczny zwrócił uwagę na to, że niemieccy osadnicy nazywali staroniemieckim wyrazem slahta (dosł. rodowcy [od ród]) ludność rodzimą polską. Jej cechą była organizacja rodowa (zob. F. Koneczny, Polskie Logos i Ethos. Roztrzasanie o znaczeniu i celu Polski, Poznań 1921, t. I, s. 50-51).

${ }^{17}$ H. Schmitt, Dzieje narodu polskiego od najdawniejszych do najnowszych czasów potocznie opowiedziane [przez Henryka Schmitta], t. I, Lwów 1863, s. 1.

18 Zob. D. Kubicki, Slawizacja chrześcijaństwa bizantyjskiego jako nowe badawcze wyzwanie, analogiczne do rozpoznanej germanizacji chrześcijaństwa tacińskiego [w druku]; tegoż, W sprawie slawiza- 
pomnażał ją na sposób kwalitatywny. Czy bowiem prawa wolnościowe ${ }^{19}$ wespół z innymi: autonomii władzy duchowej i doczesnej ${ }^{20}$, skuteczne podjęcie prawnego zmagania w sporze $\mathrm{z}$ Krzyżakami w obronie suwerennościowej

cji chrześcijaństwa łacińskiego, [w:] De catechizandis adultis. Opuscula Romualdo Niparko septuagenario dedicata, Poznań 2014, s. 129-146.

${ }^{19}$ Tzw. przywilejem czerwińskim szlachta polska uzyskała zabezpieczenie nietykalności dóbr i mienia; król nie mógł odtąd konfiskować własności prywatnej bez wyroku sądowego. W roku 1430 sformułowano inne doniosłe prawo: nietykalności osobistej, wyrażone w ustawie zasadniczej: „neminem captivabimus nisi jure victum”. Poręczało ono, że szlachcic nie będzie uwięziony inaczej, jak na podstawie prawomocnego wyroku sądowego, wyjąwszy schwytanie na "gorącym uczynku” zabójstwa, podpalenia, kradzieży i gwałtu (por. A. Chołoniewski, Duch dziejów Polski, Kraków 1917, s. 18). Przywołując powyższe - wraz z przypomnieniem angielskiej Wielkiej Karty Swobód (1215) z art. 39., zabezpieczającym od aresztu każdego wolnego obywatela, węgierskiej Złotej Bulli czy aragońskiej justicia, stojącej na straży nad rzeką Ebro - pragniemy uwrażliwić na kwestię różnych rozwiązań personalizmu cywilizacyjnego przyjmowanych przez wspólnoty narodowe i państwowe mediewalnej Christianitas. Różniły się one znacznie od tych, które organizowały państwa poza łacińską Christianitas, zwłaszcza późniejsze państwo moskiewskie - Rosję carów. W sumie polska wspólnota kulturowa nie pozostawała wyjątkiem, ale jak każda tkwiąca w mediewalnej Christianitas naznaczona była swą niepowtarzalnością (zob. W. Konopczyński, O wartość naszej spuścizny dziejowej, [w:] tegoż, O wartość naszej spuścizny dziejowej. Wybór Pism, Kraków 2009, s. 306-307). Jednocześnie zauważmy, że prawa wolnościowego nie sformułowały w tymże okresie dziejów państwa i księstwa świata germańskiego i świata ludów pod jarzmem mongolskim - a zwłaszcza te, z których wyrosły oraz wykształciły się dwie przyszłe agresje na świat Słowian: moskiewska i prusko-brandenburska.

${ }^{20}$ Pozwolimy sobie przypomnieć, że społeczność polska przeżyła na niemal stulecie przed społecznościami zachodnioeuropejskimi najbardziej wczesny etap sporu o inwestyturę, faktycznie umożliwiający i zarazem konstytuujący cywilizacyjną tożsamość kręgu pofrankijskiego Zachodu. Spór zakończył się w polskiej lokalności łacińskiego obrzeża wpływów kulturowych śmiercią Stanisława ze Szczepanowa (przed 1040-1079), późniejszego św. Stanisława - męczennika, i stanowił na jedno stulecie przed podobnym wydarzeniem w królestwie Anglii (Tomasz Becket [Thomas Becket, Tomasz z Canterbury] (ok. 1118-29 grudnia 1170 r.); kanclerz Anglii i arcybiskup Canterbury - kanonizowany w 1173 r.) zwiastun przyszłego rozdziału władzy doczesnej (świeckiej) od duchowej. A należy pamiętać, że to wraz z męczeństwem Thomasa Becketa rozgorzał on ówcześnie dopiero na dobre, doprowadzając do skutecznego odnalezienia dobrodziejstwa autonomii „władz” pomiędzy funkcjonowaniem społeczeństwa w historycznej egzystencji a transcendentalnym [chrześcijańskim] odniesieniem spełniania się w człowieczym jestestwie każdego [wierzącego], tworzącego i stanowiącego wspólnotę (określoną polis czy określony etnos) poprzez społeczne relacje. Oczywiście, nie wyrażano autonomii władzy doczesnej i duchowej (chrześcijańskiej) w takimże określeniu, lecz tak właśnie należałoby ją wyrazić na sposób dojrzały, z perspektywy współczesnego stanu nauk - uwzględniając naukę teologiczną. Ów rozdział władzy postrzegamy wyraziście jako istotny i ważny; zauważamy bowiem, że płaszczyzny inteligibilnego rozumienia Hellady - zwłaszcza jej czołowych myślicieli (Platon, Arystoteles) (por. E. Voegelin, Platon [Plato], tłum. A. Legutko-Dybowska, Warszawa 2009; tegoż, Arystoteles [Aristotle], tłum. M. J. Czarnecki, Warszawa 2011) - doświadczenia transcendentalnego $\mathrm{z} \mathrm{w}$ miarę doskonałym wypracowaniem funkcjonowania polis zostały jednostronnie zapoznane na korzyść jurydyczności w państwie, republice, a następnie cesarstwie rzymskim aż po ich zniweczenie i rozmycie u schyłku starożytności śródziemnomorskiej wraz z nastaniem tzw. ery konstantyńskiej w 313/333 r. (zob. P. Pierrard, Historia Kościoła katolickiego [Histoire de l'Église catholique], tłum. T. Szafrański, Warszawa 1984, s. 44n) w Imperium Romanum, kiedy na- 
godności ludów pogańskich na Soborze w Konstancji (1414-1418) w przedłożonym traktacie De potestate papae et imperatoris respectu infidelium Pawła Włodkowica (ok. 1370-ok. 1435) ${ }^{21}$, bądź wreszcie tzw. artykuły henrykowskie ${ }^{22}$ aż po Konstytucję 3 maja z 1891 r. - nie stanowią i zarazem nie są tego żywym i wystarczającym przykładem?

Kiedy więc z perspektywy wydarzania się kulturowości i cywilizacyjności narodu polskiego w systemacie ustrojowo-politycznym Rzeczypospolitej Obojga Narodów postrzegamy twórczą aktywność naukową, wynikającą i zarazem integralnie osadzoną na czynie egzystencjalnym Augusta hr. Cieszkowskiego, nie sposób pominąć jeszcze jednego istotnego aspektu - najbardziej istotnego. Oto bowiem wraz z osadzeniem się w perspektywie wytyczonej przez trzech reformatorów i fundatorów świata nowożytnego: Lutra, Kartezjusza i Rousseau, i to nadto w złudnym mniemaniu nawrotu do starożytnego źródła, które $\mathrm{w}$ istocie okazało i było hellenistyczne (orientalne) - nie zaś helleńskie - nowożytność rozstawała się (w uproszczeniu) z filozoficznym ideałem namysłu krytycznego nad physis rzeczywistości, jaki znamionowany był przez mądrość teoretyczną, czyli „mądrość rozumu”, powodowaną bezinteresownym "oglądem rzeczywistości”, kontemplacją sięgającą ostatecznych przyczyn świata osób i rzeczy - physis z wyróżnionym w niej oikoumene.

W sumie nowożytność europejska nie podążyła perspektywą bezinteresownego poznania rzeczy niejawnych z natury, która to bezinteresowność - inaczej: niezawisłość sądu intelektualnego i inteligibilnego - stanowiła wyznacznik niepowtarzalności filozofii greckiej (helleńskiej) na tle innych przedsięwzięć racjonalizujących starożytności - aż po dobę Platona i Arystotelesa (w uproszczeniu). I kiedy dogłębniej zastanowimy się nad wrodzoną człowiekowi potrzebą, która zrodziła mowę i sztukę pojęciowego myślenia, pamiętając jednocześnie, że myślenie pojęciowe usprawniło się dzięki wynalazkowi pisma - fonetycznego i symbolicznego (resp. logistycznego) - a na-

stąpiło przyporządkowanie chrześcijaństwa władzy cesarskiej w Kościele cesarskim (w uproszczeniu).

${ }^{21}$ Przypomnijmy najbardziej fundamentalne dwie tezy Włodkowica postawione $\mathrm{w}$ dziele O władzy cesarza i papieża nad niewiernymi. Jedna stanowiła, iż wobec pogan obowiązują te same prawa, co względem chrześcijan, oraz druga, że nie wolno narzucać wiary przemocą. Nie sposób nie podnieść, iż obie podważały najbardziej podstawową rację teorii cesarstwa i związanej z nią racji bytu zakonu krzyżackiego.

${ }^{22} \mathrm{~W}$ tymże niepowtarzalnym - i nie powtórzonym w dziejach (łacińskiego) Zachodu wzroście kultury cywilizacyjnego zrzeszania się aktywny i twórczy czyn polskiej szlachty, polskich „rodowców” (jako ówczesnej klasy średniej i średniego ruchu egzekucyjnego - w uproszczeniu), domagał się i zarazem zainicjował naprawę państwa, wprowadzając de facto pierwszą konstytucję - nieznaną jeszcze nikomu, żadnym ówczesnym władztwom i królestwom Europy; taki bowiem - wprost konstytucyjny - charakter wykazywały tzw. artykuły henrykowskie (1573). 
stępnie w społeczności Jonii egzystencjalnie niejako wymusiła namysł nad rzeczywistością - physis z zawartą w niej oikoumene - to nie wydaje się, aby wszystko i cały bezinteresowny rozwój kultury intelektualnej i inteligibilnej miał się wyczerpywać na tychże właśnie bezinteresownościach: potrzeby mowy ludzkiej, potrzeby myślenia pojęciami i potrzeby bezinteresownego poznania rzeczy niejawnych z natury.

Ośmielamy się sądzić i zarazem stwierdzać, że niewątpliwie nowożytne spaczenie wiary, spaczenie rozumu i wypaczenie uczuć czyniło impas w możliwości wyczerpującego podążania kultury zachodnioeuropejskiej - perspektywą tego kontemplatywnego w sumie rozwoju, angażując się wyłącznie w racjonalistyczność typu skutkowo-przyczynowego. A przecież nawet, gdybyśmy przyjęli, że myśl intelektualna pozostaje wyznacznikiem każdego człowieczego działania, to jednak należy przede wszystkim rozpoznać i uznać, że człowiecze dzieje nie stanowią wyłącznie historii intelektualizmu. W glorii życia dzieje człowieka w ogóle i człowieczych zbiorowości - wspólnot i społeczeństw - pozostają przede wszystkim spełnianiem się w jestestwie. Człowiek nie jest wyłącznie intelektem bądź instynktywną jednostką, ale osobą - właśnie przez spełnienie się w jestestwie w glorii życia.

Konfrontacja tejże płaszczyzny imperialistycznego rozwoju zachodnioeuropejskich państw europejskiej nowożytności z kulturowością polską i systematem cywilizacyjnym Rzeczypospolitej, integrującej w tymże systemacie Korony polskiej dobrowolnie przyłączające się doń sąsiedztwa etnicznie słowiańskie i wszelkie inne pozwala nam współcześnie pełniej i wyraziściej rozpoznać to, co wydarzyło się w agresywnym unicestwieniu Rzeczypospolitej przez mocarstwa zaborcze. Czyżby zatem nastałe tragiczne okoliczności dziejów polskiego narodu (1795-1918) pozwoliły jedynie rozpoznać kolejną bezinteresowność, a wraz z nią głębszy sens człowieczego spełniania się w jestestwie w kulturowo dojrzałej kontemplatywnie oikoumene? Tak więc uchwyciliśmy najważniejszą płaszczyznę, w której wychwyceniu uczestniczyło także i przede wszystkim pokolenie Augusta hr. Cieszkowskiego. Współcześnie bowiem dostrzegamy to, co nadal pozostaje niezrozumiałe dla europejskich "hien" imperialistycznych - i to zarówno zachodnich, jak i wschodnich, że na oczach autora Ojcze Nasz dokonało się bezinteresowne spełnianie się w jestestwie $\mathrm{w}$ akcie ofiary za braci - kulturową wspólnotę bezpaństwowego narodu Rzeczypospolitej - spełnienie w akcie dobrowolnej ofiary wobec bezwzględnie brutalnej przemocy barbarzyńskich agresorów, zasadniczo caratu moskiewskiego, jak i pruskiego absolutyzmu. 


\section{Opus badawczo-pisarskie Augusta Cieszkowskiego rezultatem twórczej interaktywności egzystencjalnego wtopienia w dzieje narodu polskiego i tkwienia w kulturowości narodu Rzeczypospolitej a spełnienia się w jestestwie $\mathbf{w}$ glorii życia w polskiej oikoumene}

W zakończonym etapie rozważań przywołaliśmy istotną różnicę dziejów polskich od dziejów innych systematów etniczno-państwowych, wyrażającą się w tym, że polskie dzieje stanowią zasadniczo dzieje narodu, wszystkie inne zaś - dzieje królów lub książąt. Rozpoznanie powyższe wyraźnie odwzorowuje się $\mathrm{w}$ różnicy postawy chociażby niemieckich myślicieli i filozofów dziewiętnastowiecznej epoki i polskich, a pośród nich Augusta hr. Cieszkowskiego. Dość łatwo bowiem można by rozpoznać filozofów niemieckich schyłkowego oświecenia jako swoiste "trybiki" (w dość sporym uproszczeniu) w mechanizmie systematu państwa pruskiego, pełniące inteligibilną posługę wobec oświeconego władcy absolutnego i jego państwa-władztwa. Takowe znamię nie stanowiło jednak charakterystyki myślicieli polskich, spośród których przywołalibyśmy Józefa Marię Hoene-Wrońskiego ${ }^{23}$ (1776-1853) bądź Maurycego Mochnackiego (1803-1834) - i to zwłaszcza z tegoż XIX stulecia jako epoki niebywałych przemian polityczno-społecznych. Niczym starożytni filozofowie jońscy, zainteresowani całością glorii życia człowieczego (w uproszczeniu) i w takiejże jej całości formułujący namysł nad wydarzającą się ludzką oikoumene w physis rzeczywistości bądź physis w wyróżnionej oikoumene, filozofowie polscy doby zaboru Rzeczypospolitej i wykreślenia jej z mapy państw europejskich podjęli oryginalny namysł nad kulturowym spełnianiem się kulturowych oikoumene w cywilizacyjnych systematach państw w dziejach. Właśnie bardziej w typie starożytnego filozofa jońskiego - Talesa, rozpoznawanego z umiejętności spożytkowania wiedzy w osiąganiu zamożności ${ }^{24}$, niż $\mathrm{w}$ postawie współczesnych mu filozofów niemieckich doby oświecenia - Immanuela Kanta (1724-1804) czy Georga F.W. Hegla (1770-1831), przychodzi nam rozpoznać integralnie związany z działalnością społeczno-gospodarczą i polityczno-naukową namysł Cieszkowskiego nad wydarzaniem się polskiego bytu narodowego. Wystarczy bowiem porównać życiowy czyn autora Ojcze Nasz, wypełniony działalnością społecz-

${ }^{23}$ Właśc. Jan Hœne - filozof metafizyk, filozof wychowania, matematyk, astronom, fizyk, technik wynalazca, prawnik, ekonomista.

24 Znana bowiem była dalekowzroczność Talesa, wedle której, przewidując na podstawie swej wiedzy astronomicznej wyjątkowy urodzaj oliwek, wydzierżawił na długo przed zbiorem wszystkie okoliczne prasy do tłoczenia oliwy, dorabiając się w tak prosty sposób znacznego majątku (por. Diogenes Laertios, Żywoty i poglądy stynnych filozofów, tłum. I. Krońska, Warszawa 2006, s. 23). 
ną i gospodarczą, którą inicjował we własnych majątkach i zaprzyjaźnionych z nim majątkach właścicieli ziemskich Wielkopolski, wyrażającą się w organizacji sprzedaży płodów rolnych, racjonalnego pozyskiwania drewna, inwestowania w inwentarz żywy oraz budynki i sprzęt rolny, stosowania kredytu hipotetycznego, upraw, wynagradzania robotników rolnych itd. ${ }^{25}$, do wąsko zorientowanej namysłem filozoficznym działalności uniwersyteckiej Kanta i Hegla, których nie sposób nie postrzegać poza wydarzającym się czasem epoki, czerpiącej z zasobu ich systematów świata deterministycznie w sumie (w uproszczeniu) skonstruowanych idei. Osiadłemu w Wierzenicy jako właściciel majątku ziemskiego i mieszkającemu w Poznaniu przyszło rozwijać coraz bardziej dogłębnie swą aktywność organizacyjną na rzecz - w sensie wręcz dosłownym - pracy organicznej - tym bardziej, że znajomość idei furieryzmu oraz niemieckiej i angielskiej myśli agrarnej pozwalała mu zdobywać autorytet $\mathrm{w}$ gremiach farmerów ${ }^{26}$ tychże krajów oraz polskiego, rodzimego ziemiaństwa ${ }^{27}$.

Wprost przeciwnie do idei, które rozpalały umysły środowisk robotniczych epoki porewolucyjnej, inspirując do buntu, nie angażował się w dyskursy ideologiczne, ale osadzając się na konkrecie życia kulturowej oikoumene podnosił - jak np. podczas Kongresu Rolniczego w Berlinie w 1845 r. - potrzebę udziału robotników rolnych w dochodach majątków ziemskich, propagując tworzenie lokalnych przedsiębiorstw przetwórstwa rolno-spożywczego, czyli zakładów mięsnych, mleczarskich, młynarskich i gorzelnianych, a także przedsiębiorstw produkujących materiały dla rolnictwa, czyli tartaków, cegielni, kuźni i warsztatów [powozowych]. Ale August hr. Cieszkowski autor Ojcze Nasz - nie ograniczył się w propagowaniu idei zakładania kółek rolniczych i grup producentów rolnych - w tym także hodowli koni i bydła rasowego. Konsekwentnie do swych ideałów - które można by streści jako ideał życia integralnego - propagował oświatę ludową, zwłaszcza rolniczą wraz z edukacją rzemieślniczą ${ }^{28}$. Jego przekonania nie stanowiły wyłącznie zapisanych w pismach postulatów bądź idei. Po dekadzie usilnych starań założył w 1870 r. w Żabikowie Szkołę Rolniczą - na poziomie szkoły wyższej, noszącą imię zmarłej małżonki Haliny. Powstanie tego ośrodka nie tylko wzmacniało czy intensyfikowało upowszechnienie najnowszej wiedzy o zdobyczach agronomiczno-technicznych krajów zachodnich pośród ziemiaństwa w kadrach przyszłych odpowiedzialnych za uprawy w majątkach ziemiaństwa jako absolwentów szkoły, ale jednocześnie wypełniało wielkopolską pustkę (w uproszczeniu) i zarazem organizowało ośrodek badawczy, sku-

${ }^{25}$ Por. K. Wojnowski, Wstęp. August hr. Cieszkowski, s. 15.

${ }^{26}$ Zwróćmy również uwagę na rozróżnienie, jakie stosujemy, w odróżnieniu farmerów i rodzimego ziemiaństwa.

27 Por. K. Wojnowski, Wstęp. August hr. Cieszkowski, s. 15.

${ }^{28}$ Por. tamże, s. 16. 
piając wybitnych ówczesnych uczonych w osobach Profesorów: Szczęsnego Kukiełki, Józefa Rivoli ${ }^{29}$ (1838-1926) i Kazimierza Graffa.

Ale działania organizacyjne w wymiarze edukacji rolniczej nie wyczerpywały aktywności Cieszkowskiego. Zapewne dostrzegając imperatyw wychowawczo-edukacyjny społeczności wiejskiej równolegle zabiegał w sprawach organizacyjnych ludowej oświaty i edukacji, a wychowanie dzieci i edukacyjną opiekę nad nimi rozumiał w perspektywie organicznego kształcenia wykwalifikowanej siły roboczej dla rolnictwa i rzemiosła, a jednocześnie nowo organizujących się i powstających fabryk. Było to przecież stulecia, którego pokolenia europejskich oikoumene naznaczone zostały - stopniowym bądź gwałtownym, w zależności od regionu - przejściem od manufaktury i rękodzieła rzemieślniczego do fabryk i masowej produkcji. Wiemy z perspektywy współczesności, że był to czas równoległego formułowania teorii społecznych, dotyczących kapitału i nowo wykształcającej się klasy społecznej - proletariatu [fabrycznego]. Wiemy również, ale jedynie z perspektywy współczesnych badań myśli polityczno-społecznej ówczesnych epigonów ideologii postępu "cywilizacyjnego" i nowej ludzkości, iż Karol Marks ${ }^{30}$ (1818-1883) trafnie pojął bezosobową naturę kapitału, dążącego do osiągnięcia i pomnożenia zysku, jednocześnie nieprzezwyciężalnie tkwiąc $w$ niewoli ideologicznej swych poprzedników, czyli Marcina Lutra i Kartezjusza, a zwłaszcza Jean J. Rousseau, co do rozumienia natury człowieczej. Uznał ją bowiem za bezgrzeszną i deformowaną jedynie przez własność prywatną (resp. kapitał).

Życiowa postawa Augusta hr. Cieszkowskiego przeczy zachodzeniu wszędzie i pod każdym względem najbardziej podstawowej tezie autora $\mathrm{Ka}$ pitału, iż natura człowieka jest - jak rozpoznawał Marks - całokształtem stosunków społecznych. Być może okazuje się [intelektualnie] „wywiedzioną” z obserwacji stosunków ekonomicznych i gospodarczych imperialnych mocarstw kolonialnych Europy Zachodniej i np. farmerów zachodnioeuropejskich obszarów rolnych. Jednak badawczo obserwując aktywność i zaangażowanie Cieszkowskiego jako ziemianina i właściciela majątku ziemskiego, nie sposób nie rozpoznać, że z naczelną tezą Marksa jest akurat wprost przeciwnie - i to, jeżeli nie w zachodnioeuropejskich stosunkach gospodarczo-ekonomicznych, to przynajmniej w odniesieniu do sytuacji polskiego ziemiaństwa doby "organicznej pracy u podstaw". Dość łatwo rozpoznajemy, że to raczej rola społeczna kapitalisty czy też ziemianina kształtuje skutecznie te stosunki społecznie. I doskonale można rozpoznać, że kształtowanie tychże stosun-

${ }^{29}$ Plenipotent i zarządca dóbr kórnickich (1863-1876); założyciel (1866) i prezes zrzeszenia polskich leśników (1866-1916), działającego jako wydział leśny Centralnego Towarzystwa Gospodarczego w Wielkim Księstwie Poznańskim; wykładowca w Wyższej Szkole Rolniczej w Żabikowie (1874-1875); od 1919 pracownik naukowy uniwersytetu w Poznaniu.

${ }^{30}$ Właściwe: Karl Heinrich Marx. 
ków dokonywało się poprzez przywołane powyżej zaangażowania i przedsięwzięcia gospodarczo-oświatowych Cieszkowskiego.

Czyżby tego niesprawdzania się tez Marksa - przynajmniej w warunkach polskiej cywilizacyjności - nie należałoby dostrzegać $\mathrm{w}$ systemacie narodu Korony polskiej, który kształtowany był oddolnie - od społeczeństwa szlacheckiego: rodowców, organizującego się samorządnie oddolnie? W tejże perspektywie należałoby konsekwentnie rozpoznać odmienne kształtowanie się kulturowości polskiej i tkwienie w niej coraz to nowych pokoleń. Bowiem w odniesieniu do młodego Cieszkowskiego, czyżby należałoby przywołać, że przecież przyszły autor Ojcze Nasz otrzymał wychowanie w duchu głęboko patriotycznym, jakie nadał mu dom rodzicielski, a także grono jego guwernerów jako dorastającego obywatelsko młodzieńca? Przecież zawiodło go na ono na „budowę" warszawskich barykad. I chociaż jako siedemnastoletni młodzieniec nie brał udziału w bezpośredniej akcji zbrojnej - dopowiedzmy: ze względu na stan zdrowia, a wszedł w skład tzw. zaplecza obronnego, to jednak doświadczył tego samego stanu przeżyć zmagania niepodległościowego, co wielu jego rówieśników z tego pokolenia - chciażby Piotr Semenenko (1814-1886), późniejszy teolog i kaznodzieja środowiska polskiej emigracji jako z założycieli zgromadzenia zakonnego Księży Zmartwychwstańców, który niestety nie miał tak, jak Cieszkowski, ziemiańskiego pochodzenia, ale znacznie skromniejsze ${ }^{31}$.

Przywołując z kolei edukację, jaką otrzymał autor Prolegomeny do historiozofii, wywieziony do Rzeczypospolitej Krakowskiej i do Krakowa przez swego ojca przed upadkiem powstania - ojca przezornie obawiającego się represji za udział w nim, nie sposób nie podnieść, że w istocie samej była ona nie tyle polska (w uproszczeniu), co wielce sprzyjająca wielowymiarowemu rozwojowi osobowości i cech charakteru, a przede wszystkim rozwojowi intelektualnemu w kulturze polskiej i poczuciu patriotycznym. Kraków bowiem - wprost przeciwnie do innych terytoriów Rzeczypospolitej pod zaborami - pozwalał na nieskrępowane nauczanie $\mathrm{w}$ języku ojczystym, posługiwanie się polskimi podręcznikami i studiowanie czy, lepiej, rozczytywanie się w literaturze polskiej. Wprowadzony w wyjątkową atmosferę życia umysłowego Krakowa - radykalnie różniącego się od surowości klimatu wykształconego przez zaborcę pruskiego czy moskiewskiego - młody Cieszkowski jeszcze jako uczeń Liceum św. Barbary został skutecznie zaznajomiony z trendami umysłowymi epoki. Otrzymał zresztą ku temu odpowiednie przygotowanie nie tylko edukacją prywatną i znajomością kilku obcych języków, ale także odbytymi podróżami po kilku krajach europejskich i po terytoriach wszystkich trzech zaborów ${ }^{32}$. Również przezorności ojca należy oddać rozpoznanie

31 Zob. D. Kubicki, Polska emigracyjność w myśli teologicznej Piotra Semenenki CR (1814-1886), „Przegląd Polsko-Polonijny” 2012, r. 4, nr 2, s. 19-38.

32 Por. J. Hellwig, Cieszkowski, Warszawa 1979, s. 17. 
wszechstronnych zainteresowań, zmysłu badawczego i sprawności pretendujących do uprawiania nauki; przecież pod jego wpływem August Cieszkowski zapisał się na Wydział Filozoficzny Uniwersytetu Jagiellońskiego, ówcześnie zreformowanego. Zreformowana Wszechnica Wolnego Miasta Krakowa zapełniona była uczonymi, którzy poza granicami zaboru dali skutecznie się rozpoznać w naukowych osiągnięciach. Cieszkowski jako student miał więc możność wkroczenia w dosłownie czystą filozofię pod kierownictwem profesora filozofii Józefa E. Jankowskiego - ówcześnie wybitnego kantysty. Ale świat nastawionego heterodoksyjnie do utartych schematów myślowych Jankowskiego nie był jedynym, w który wkroczył autor Ojcze Nasz. W zakresie problematyki pedagogicznej i psychologicznej słuchał wykładów prof. Michała Wiszniewskiego ${ }^{33}$ (1794-1865) - historyka literatury polskiej, który w swej życiowej drodze miał doświadczenie działacza politycznego w powstaniu krakowskim w 1846 r. Właśnie to on w pierwszej kolejności wywarł istotny wpływ na Cieszkowskiego swą postawą patriotyczną wraz z niezwykłą aktywnością społeczno-polityczną i naukową, a także założeniami swoich koncepcji i twierdzeń psychologiczno-pedagogicznych ${ }^{34}$.

W sumie, przebywając przez niezwykle krótki czas na studiach uniwersyteckich w Krakowie, autor Ojcze Nasz miał możność oprócz zapoznania się z różnymi dziedzinami wiedzy również wglądu do naukowego warsztatu uczonego i roli, jaką pełni w stosunku do społeczeństwa. W 1832 r. udał się na dalsze studia w Niemczech - do Berlina, do nowoczesnego ówcześnie uniwersytetu, nawiązującego do uniwersyteckiego ideału mediewalnej Christianitas, a na nowo zreformowanego i zorganizowanego przez Wilhelma Humboldta (1767-1835). Jednak ponieważ były to lata nieodległe schyłkowi życia i samej śmierci Hegla, Cieszkowski natrafił w tejże nowoczesnej placówce naukowodydaktycznej - miejscu działalności filozofa i zarazem autora Fenomenologii ducha - na przemożny wpływ filozofii i osoby Hegla-uczonego, pod którym także pozostawała cała ówczesna nauka ${ }^{35}$. Tak więc wydaje się zrozumiałym, że heglizm, będąc przedmiotem ogólnej uwagi i ówczesnej debaty filozoficznej, a zwłaszcza stając się przedmiotem dalszego etapu uniwersyteckich studiów Cieszkowskiego pod kierunkiem profesorów-heglistów, ówcześnie już sławnych uczniów mistrza Hegla, czyli Gablera, Gansa i Karola L. Micheleta ${ }^{36}$, stał się także na samym finale jego uniwersyteckich studiów przedmiotem zwię-

33 Przypomnijmy - historyk literatury, filozof, psycholog, wydawca źródeł; wychowanek i profesor Liceum Krzemienieckiego, od 1831 profesor w Uniwersytecie Jagiellońskim; podczas rewolucji krakowskiej (1846) przywódca konserwatywnego spisku, po jednodniowej dyktaturze obalony, od 1848 na emigracji we Włoszech; uznany za epigona polskiego oświecenia i prekursora pozytywizmu, autor Historii literatury polskiej (t. 1-10, 1840-1857).

${ }^{34}$ Por. J. Hellwig, Cieszkowski, s. 19.

35 Por. tamże, s. 24.

${ }^{36}$ Por. tamże, s. 26. 
złego opus naukowego: Prolegomena zur Historiosophie ${ }^{37}$, zanim przedłożył na uniwersytecie w Heidelbergu doktorską tezę z historii filozofii jońskiej: De philosophiae jonicae, vi loco. Czy zatem można w ogóle pozostawać zadziwionym, że pierwszym samodzielnym i niepisanym na ocenę - ocenę promocyjną, jak doktorska dysertacja - i to w klimacie środowiska polskiej młodzieży, studiującej dzieła myśli niemieckiej na berlińskim uniwersytecie, a radykalnie różniącej się od burszostw (resp. Burschenschaftów) ${ }^{38}$ wraz z ich pijatykami i pojedynkami środowiska lokalnego, lecz tworzących kręgi towarzyskie, które kształtowały swe życie ideowe w duchu polskim, w takiż sposób wyrażając swą odpowiedź na zakusy germanizacyjne, jakby "przygotowując" się do przyszłej roli przywódców narodowowyzwoleńczych czy narodowotwórczych - okazywało się zwięzłe rozmiarami opus naukowe: Prolegomena do historiozofii ${ }^{39}$, w którym kontynuując możliwie najwierniej rozwijany twórczo przez siebie heglizm, podjął na gruncie myśli polskiej próbę analizy dziejów ludzkich oikoumene i historii, procesu społecznego, zmiany i rozwoju przedmiotowej strony bytu wraz z rozwojem podmiotowego ducha ${ }^{40}$ ?

Studia uniwersyteckie i uzyskanie doktoratu z zakresu filozofii w uniwersytecie w Heidelbergu nie okazywały się celem samym w sobie. Autor nowo wydanej Prolegomena zur Historiosophie odbył podróż do Paryża, wielokrotnie do niego powracając w późniejszym swym życiu. Zapoznał się w nim $\mathrm{z}$ wieloma wybitnymi i znanymi w tamtym czasie myślicielami i działaczami, twórcami kultury. Poszerzył swą edukację, uczestnicząc w wybranych przez siebie wykładach na Sorbonie i w Collège de France. Skutecznie pogłębiał wiedzę z zakresu funkcjonowania organizacji i instytucji, aktywnie biorąc udział w funkcjonowaniu towarzystw naukowych - co bezsprzecznie wydatnie mu pomogło do nieodległego ówcześnie w czasie zorganizowania wraz z Karolem Ludwikiem Micheletem i założenia Towarzystwa Filozoficznego w Berlinie (1842), a także wraz z wieloma innymi Poznańskiego Towarzystwa Przyjaciół Nauk (1857) - tym razem instytucji założonej zgodnie z jego autorskimi koncepcjami. Czy może jeszcze dziwić fakt, iż obserwuje posiedzenia parlamentarne, że interesuje się działalnością gospodarczą, że zwiedza nowo powstałe fabryki i wszelkie organizacje obrotu kapitałowego, że podpatruje funkcjonujące giełdy i banki, że zapoznaje się z angielskim szkolnictwem, obserwując przełamywanie się przestarzałego poglądu, iż edukacja pozostaje wyłącznie sprawą indywidualną, a nie społeczną czy publiczną określonego systematu państwa? Niewątpliwie należy przypisywać dogłębnemu wrażeniu nad naocznym przypatrzeniem się w Anglii - dominującym ówcześnie

\footnotetext{
37 Wydane w Berlinie w 1838 r.

${ }^{38}$ Czyli korporacji studenckich (niem. Burschenschaft - korporacja studencka).

${ }^{39}$ Przełożone na polski przez syna autora, również Augusta [Adolfa] Cieszkowskiego, a wydane w Poznaniu w 1908 r.

${ }^{40}$ Por. K. Wojnowski, Wstęp. August hr. Cieszkowski, s. 12.
} 
imperium postępu techniczno-technologicznego i przemysłowo-gospodarczego - sytuacji nowo wykształconego proletariatu, a zwłaszcza fabrycznej pracy dzieci i ich dość wysokiej śmiertelności, nikłej liczbie [elementarnych jedynie] szkół i ich niskiemu poziomowi nauczania, wolę imperatywu edukacyjno-wychowawczej działalności wobec polskich wiejskich oikoumene. Rezultatem tegoż pobytu i poczynionych refleksji stało się obszerne badawcze opus $D u$ crédit et de la circulation ${ }^{41}$ oraz rozważanie Uwagi nad obecnym stanem finansów angielskich ${ }^{42}$, zawierające zarysowujące się zaczątki przekonań Cieszkowskiego, czyli idei praktycyzmu w gospodarowaniu, demokratyzmu w stanowieniu samorządności, racjonalizmu w dziedzinie edukacji oraz tolerancji w obyczajowości i kulturze ${ }^{43}$.

Wykorzystuje w sumie podróże po Francji, Anglii i Włoszech do naocznego przypatrzenia się osiągnięciom cywilizacyjnym (w sensie techniczno-technologicznym) zachodnioeuropejskich systematów państw, aby umiejętnie twórczo wykształcić własne koncepcje z zamiarem ich propagowania bądź upowszechnienia wiedzy o zdobyczach cywilizacyjnych. Ale zanim się to stanie, nabył nawet majątek we Francji i stał się (m.in.) delegatem swego regionu - czyli Basses Alpes - na kongres rolniczy w Paryżu w 1847 r., pracując w komisji kredytowej i opracowując odpowiedni raport. Zanim jednak już ostatecznie osiądzie w Wierzenicy jako właściciel majątku ziemskiego i równolegle zamieszka w Poznaniu dokonuje publikacji twórczych przemyśleń nad kwestiami administracyjno-politycznymi: $O$ izbie wyższej $i$ arystokracji $w$ izbie wyższej ${ }^{44}$, problematyką filozoficzną: Bóg i palingeneza ${ }^{45}$, zagadnieniami społeczno-gospodarczymi: Praktyczna filozofia wiejskiego gospodarowania ${ }^{46}$, oraz rozpoczętych rozważań nad historiozofią ludzkości: Ojcze Nasz ${ }^{47}$ - najbardziej znane opus magnum Augusta hr. Cieszkowskiego, nad którym nie ustawał $\mathrm{w}$ zmaganiu intelektualno-kontemplatywnym, rozciągającym się na ponad trzydzieści pięć lat jego życia.

Znamienne jest, że wysokie kompetencje praktyczne w zakresie wiedzy ekonomiczno-gospodarczej zostały dostrzeżone już w latach czterdziestych XIX stulecia, w 1859 r. zaś otrzymał propozycję objęcia urzędu ministra finansów w rządzie pruskim, którego jednak nie przyjął. Natomiast podjął aktywność w dziedzinie politycznej, działając ze skutecznym oddaniem dla polskiej

${ }^{41}$ Czyli o kredycie i obiegu [pieniądza] (Paris 1839).

${ }^{42}$ Warszawa 1842.

43 Por. tamże, s. 13.

44 Paris 1844.

${ }^{45}$ Berlin 1842.

46 Poznań 1844.

47 Ojcze nasz (t. I, Paris 1848; Paris 1870²); Wezwanie (t. II, Poznań 1899), Pierwsza prośba. Święć się Imię Twoje (t. III, Poznań 1903), Druga prośba. Przyjdź Królestwo Twoje (t. IV, Poznań 1906); Streszczenie (Wilno 1911). 
sprawy w pruskim Zgromadzeniu Narodowym, do którego zdobył mandat poselski (od 8 maja 1848 r.), a także równolegle angażował się organizowanie i rozwój lokalnego środowiska naukowego - $\mathrm{w}$ instytucjonalnej postaci rzeczonego już powyżej Poznańskiego Towarzystwa przyjaciół Nauk. Czy oddanie na jego badawcze zapotrzebowanie swego zasobu bibliotecznego o liczbie 40 tys. woluminów - z zakresu historii prawa, filozofii, ekonomii, przyrodoznawstwa, literatury, sztuki, religioznawstwa, językoznawstwa czy slawizmu - nie stanowi przekonującego argumentu o życiowej pasji faktycznego zaangażowania autora Ojcze Nasz?

Ale przede wszystkim należałoby retorycznie w pewnym sensie zapytać: czy ktoś o takimże biegu życia i rozwoju myśli intelektualnej mógłby nie podjąć swych wyjątkowych przemyśleń w skonfrontowaniu jej z intelektualnym wyzwaniem tamtej ówczesności, jaką stanowił heglizm i nie podjąć na sposób imperatywny sformułowania ich w Prolegomenie do historiozofii oraz w Ojcze Nasz? Na czym więc - badawczo postrzegając schyłek europejskiej nowożytności z perspektywy współczesnej postmoderności - polegało konfrontacyjne zderzenie świata cywilizacyjności polskiej, który egzystencjalnie stanowił punkt wyjścia refleksji Cieszkowskiego i podłoże jego intelektualnych i zarazem kulturowych odniesień, z wizją dziejów, jaka z inspiracji Hegla, autora Fenomenologii ducha, stała się udziałem dziewiętnastowiecznych elit intelektualnych europejskiego Zachodu?

\title{
3. Myśl historiozoficzna autora Ojcze Nasz przezwyciężaniem impasu intelektualnej metafizyki i wzniesieniem podwalin w rozpoznanie człowieczego spełniania się
}

\author{
$\mathbf{w}$ jestestwie $\mathbf{w}$ glorii życia
}

August hr. Cieszkowski pozostawił imponującą twórczą spuściznę pisarską: naukową i badawczą, będąc za życia niekwestionowanym autorytetem jako uczony i filozof, pragmatyczny działacz społeczno-gospodarczy i mędrzec, a nawet mesjanistyczny wizjoner. Jak zasadnie podnosi Kazimierz Wojnowski: opus intelektualne i inteligibilno-kontemplatywne było ideotwórcze i zarazem pragmatyczne, równolegle filozoficzne i naukowe (w uproszczeniu), realistyczne i mistycyzujące, analityczne i syntetyzujące jednocześnie, zawsze jednak logiczne i badawczo rzetelne oraz poznawczo uczciwe ${ }^{48}$.

Zanim podejmiemy kwestię niezwykłej nowości inspirujących badawczo treści opus filozoficzno-historiozoficznego Cieszkowskiego, pozwolimy sobie

${ }^{48}$ Por. K. Wojnowski, Wstęp. August hr. Cieszkowski, s. 19. 
powrócić do kwestii „kolapsu” cywilzacyjności mediewalnego Christianitas i wykształcenia się jednostronnego: idealistycznego ${ }^{49} \mathrm{w}$ sumie ( $\mathrm{w}$ uproszczeniu), spojrzenia na wydarzające się człowiecze oikoumene w nowożytności europejskiej, który doskonale uwyraźnia się w swych skutkach w debacie-sporze naukowym o istnienie bądź nieistnienie narodów, odbytej na początku XX stulecia - a więc już po śmierci Cieszkowskiego - pomiędzy dwoma teologami-dominikanami. Współczesny Jackowi Woronieckiemu ${ }^{50}$ OP (1878-1949) znakomity Luksemburczyk - Jean Grendt OP twierdził, że państwo ma prawo zmuszać ludzi („łagodnymi środkami”) do zmiany języka, obyczajów narodowych itd. Jako znakomity tomista wywodził swe tezy z opus Akwinatowego. Jednak ponieważ za czasów św. Tomasza narodów jeszcze nie było, więc w latach dwudziestych XX stulecia znakomita większość francuskojęzycznych tomistów nie rozumiała w ogóle, czym jest naród. Oczywiście autor Katolickości tomizmu podjął intelektualny spór z takimże stanowiskiem, podnosząc - jako jeden z pierwszych we własnym środowisku zakonnym, stanowiącym jednocześnie środowisko duchowe Akwinaty - postulat porządnego myślenia (intelektualnego) o nowych zagadnieniach, czyli $\mathrm{w}$ tejże kwestii debaty - o zagadnieniu narodu ${ }^{51}$.

Przykład tejże debaty pozwala nam dogłębniej zrozumieć przewartościowania, jakie dokonały się wraz ze schyłkiem myśli teologicznej mediewalnej Christianitas (w uproszczeniu) w sensie uprawiania refleksji teologicznej w Akwinatowej koncepcji teologii jako wiary in statu scientiae wraz z jednoczesnym uczynieniem wytworu tegoż teologicznego instrumentarium, czyli teologicznego dzieła św. Tomasza z Akwinu, absolutnym odniesieniem każdej kwestii intelektualnej, jaka miałaby się pojawić. Lecz nowożytność europejska nie tylko „umetafizyczniła” opus teologiczne Akwinaty - również Corpus Platonicum i Corpus Aristotelicum, podobnie jak myśl i pisarskie dzieło teologiczne Marcina Lutra, zostały na podobny sposób potraktowane, czyli „umetafizycznione" w sensie wyjęcia z ram czasowości i przestrzenności physis (w uproszczeniu), uczynione rodzajem absolutu bądź nabierając charakteru absolutnego i jakby ostatecznego. Dopiero wraz z wypracowaniem metody historyczno-krytycznej zdaliśmy sobie sprawę z wymiaru historycznego wydarzania się świata osób i rzeczy. Ale zanim to nastąpiło, konieczne było w przestrzeni badawczej XX stulecia rozpoznanie historycznego wymiaru opus Akwinaty, Platona i Arystotelesa. Pozostaje nadal do rozpoznania takiego samego wymiaru w stosunku do pisarskich opus fundatorów nowożytności - wraz z wyciągnięciem wszystkich (egzystencjalnych, a także społecznych

${ }^{49} \mathrm{~W}$ sensie rozumienia rzeczywistości świata wedle koncepcji Idei Platona - świata "cieni".

50 Czyli książę Adam Korybut zanim przybrał imię zakonne.

51 Zob. J. Woroniecki, Katolickość tomizmu, Lublin 1924. 
i politycznych) konsekwencji z takiegoż stanu rzeczy. Nadto sam proces „odmetafizycznienia" tego, co uległo weń wtopione u progu nowożytnego świata za przyczyną podmiotowego "Ja" i świata nie-,„Ja" Kartezjusza, sola fides, sola scriptura $i$ sola gratia Lutra oraz założenia złych instytucji społecznych i dobrej człowieczej natury wraz z imperatywem konieczności uwolnienia człowieka od gnębiących go warunków społecznych, aby dopełniła całej reszty wykształcenia od podstaw nowego społeczeństwa jego dobra $\mathrm{z}$ samej swej istoty natura [ludzka] Rousseau, nie wydaje się zakończony. Zresztą myśl intelektualna nad wydarzaniem się społeczeństw bądź nad ustalaniem podstaw ideologicznych do konstruowania nowych zamierzeń względem „ludzkości” (jako „bożka” w uproszczeniu) w sensie Augusta Comte'a (1798-1857) nie stanowi jednorodnego monolitu. Biegnie różnymi ścieżkami ideowo-ideologicznymi, opierając się na różnych podłożach, nie sięgając najbardziej pewnego podłoża inteligibilnego (w uproszczeniu). Wystarczającym przykładem jest chociażby zagubienie rozumienia uchwyconej w kategoriach poznawczej bezinteresowności i wyartykułowanej przez starożytnych człowieczej sprawności theoría - czyli sprawności bezinteresownego poznania rzeczy niejawnych z natury - poznania w mądrości teoretycznej (od theos ${ }^{52}$ ) w bezinteresownym "oglądzie rzeczywistości" ostatecznych racji i przyczyn tegoż świata osób i rzeczy.

52 Na bardziej uważną badawczą uwagę zasługuje grecki termin theoría. Przypomnijmy termin theoria wyraża jedną z zasadniczych cech myśli starożytnej, jeśli nie jej cechę najbardziej typową; z perspektywy dziejów badawczo dostrzeżono, jak z postawy poznawczej i moralnej człowieka ulega transformacji w moc (resp. energię) bytotwórczą w neoplatonizmie (zob. G. Reale, Historia filozofii starożytnej, t. I, Od początków do Sokratesa, tłum. E.I. Zieliński, Lublin 1994, s. 469-498). Chodzi o hojne głębia intelektualną myślenie (namysł nad Rzeczywistościa, metamyślenie), osiągane wyłącznie $\mathrm{w}$ bezinteresownym trudzie poznania rzeczy stanowiących (nie-empiryczną, a przyczynowa w sensie theoria Arystotelesa) istotnościowa (w sensie eidos starożytnych) głębię wydarzającej się rzeczywistości. Równie inteligibilnie niezauważone zdaje się pozostawać rozumiejące oglądanie rzeczywistości. A przecież stanowi jako postawa poznawcza najwyższy przejaw życia w możności kontemplatywnego oglądu physis rzeczywistości: gnónai kai theorésai. W konsekwencji życie człowiecze pozbawione bíos theōrētikos traci swój najgłębszy sens - także w znaczeniu „ponad-człowieczej” (resp. zdolności) „mocy” w człowieku jako możliwości sformułowania intuicyjnego zapytania o zasadę, przyczyny i elementy physis [jako całość] wraz z kierowaniem inteligibilnego zainteresowania racjonalną odpowiedzią jako pozostającej udziałem jej Stworzyciela, będącego Pierwszą Przyczyna (w sensie Arystotelesa) jej zaistnienia, bytowania itd. Dopowiedzmy nadto - jest zrozumiałe, że inspirując się zasadnym spostrzeżeniem niemieckiego uczonego (filologa) Ulricha von Wilamowitz-Moellendorffa (1848-1931) - twórcy metody historycznej w filologii klasycznej, iż greckie słowo: theos (opisujące boga Platona), występuje zasadniczo w funkcji predykatywnej, powinniśmy konsekwentnie przepracować dotychczasowe stanowiska intelektualne, które wyznaczyły i zarazem wyznaczały dotychczasowe osadzenia intelektualne dla ustalania bądź kształtowania bardziej ogólnych tendencji dla wszystkich dyscyplin szczegółowych. W kwestii powyżej przywołanych ustaleń Wilamowitza, które pozwalają nam rozpoznać, iż w odróżnieniu od chrześcijan Grecy nie stwierdzali istnienia Boga, aby konsekwentnie, jak ci pierwsi, w dalszym etapie refleksji intelektualnej podejmować skuteczne próby wyliczenia jego atrybutów, ale określali wyrażeniem theos każde zjawisko ponadczłowiecze, wieczne (w sensie nieprzemijania, nie ustawania), każdej mocy postrzeganej 
Można by podnieść w stosunku do całościowej powyższej kwestii błędnego inteligibilnego fundamentu nowożytności, że nie tyle bez wyczerpującego i ostatecznego przezwyciężenia owej dychotomii na - z jednej strony - jakąś bliżej nieokreśloną metafizyczność, z drugiej zaś - na pragmatyczność i zewnętrzność wydarzającej się rzeczywistości physis świata, ale także bez rozpoznania kontemplatywnej sprawności człowieczego podmiotu - rozpoznawania ostatecznych przyczyn rzeczywistości physis, której sobą doświadcza i przeżywa na sposób dogłębniejszy i bardziej pełny, losy cywilizacyjne społeczeństw Zachodu w ich fundacyjnej istotności, niezwykłości i niepowtarzalności stają pod znakiem zapytania, a społeczeństwa czynione globalnymi pozostają skazane na karłowacenie ducha cywilizacyjnego. Innymi słowy, losy całego Zachodu - co jeszcze bardziej dobitnie współcześnie uwyraźnia się zależą od tego, czy potrafi przezwyciężyć błędy fundujące "duchowość" nowożytną.

Po tymże nakreśleniu szerszej perspektywy pozwolimy sobie przejść do uwydatnienia istoty myśli historiozoficznej Cieszkowskiego. Ale zanim to uczynimy, nie sposób nie przywołać i nie przypomnieć - przynajmniej w schemacie - konstrukcji świata nowożytności europejskiej, czyli tego, - oprócz tego, że opierał się na zasadach bezwzględnej polityki ${ }^{53}$, opisanej w Il Principe Nicolò Machiavellego, to przede wszystkim stanowił zinterpretowanie Platońskiej Idei, pojmując go w kategorii „,świat cieni” , który w istocie należało rozumieć jako niebyt. W kontekście odrzuconego rozumienia arystotelesowo-akwinatowego rozpoznania świata w kategoriach materii pierwszej i „ustanowionego" w koncepcji Kartezjańskiej (epistemologicznego) rozdziału między podmiotem i przedmiotem, materią i duchem - podmiotowym „Ja" i światem nie-„Ja", a więc w kontekście zwłaszcza prób bardziej konkretnego „podążania” perspektywą interpretacji platońskiej, czyli materią zmysłową Kanta bądź dopuszczaniem czegoś irracjonalnego w rzeczywistości przez Schellinga, „wzniesione” na Plotynowej materii - „odpadku” Bóstwa, przekonanie Hegla, że myśl i rzecz pozostają tym samym (resp. identyfikują się), przekraczając w sumie transcendentalny idealizm, stanowiły bardzo atrakcyjną perspektywę dla ówczesnych myślicieli. Nie dostrzegano wówczas jeszcze negatywnych konsekwencji tego nad wyraz ostrego (resp. skrajnego) idealizmu ontologicznego, który nakazywał konsekwentnie rozpoznać, iż w rzeczy samej świat jest całkowicie przezroczysty dla myśli - w sensie, że nie ma w nim niczego, co nie można by ująć w pojęcia.

w zewnętrzności i wewnętrzności (w uproszczeniu) physis, która nie okazuje się być zrodzona wraz z człowiekiem i nie wyczerpuje się, nie znika czy nie odchodzi wraz z nim, a szerzej z człowieczymi oikoumene (por. G.M.A. Grube, Plato's Thought, Methuen 1935, s. 150).

${ }^{53}$ Czyli „dziel i rządź”, , "cel uświęca środki” itd. 
Tak właśnie empiryczno-materialistyczny wymiar „interpretował” i postrzegał w rozumieniu Hegel - autor powszechnie przemyśliwanej ówcześnie Fenomenologii ducha. Ale wymiar duchowy i duch w sensie Hegla nie stanowił tego, co w tymże pojęciu (resp. terminie) i zarazem koncepcie myślnym rozumiało wówczas i nadal rozumie chrześcijaństwo (w uproszczeniu). Dopowiedzmy Hegel rozumiał ducha jako gnostycką, bliżej nieokreśloną, nieosobową siłę. I chociaż Logosem określił Hegel swe Bóstwo, to jednak „logika" tejże "Siły"-„Mocy” nie wykazuje nic wspólnego ani z Logosem w sensie Jończyków, ani z logosem i logiką w sensie Arystotelesa. Co najwyżej dalekim nawiązaniem do niego pozostaje ujęte przez Hegla w sensie kategorii ontycznych Istnienie (Dasein) w postaci najbardziej oderwanego pojęcia - bytu, wraz ze swą antytezą, czyli niebytem i jednocześnie "ustanawiającą" się (w uproszczeniu) ich syntezą - ruchem łączącym byt (Istnienie) i niebyt (Nieistnienie). Lecz dialektyczna trójka nie wyczerpuje się na powyższym. W podobnym bowiem dialektycznym schemacie rozpoznane zostały następnie dalsze „trójki”: dusza-świadomość-rozum, rozpoznana jako duch podmiotowy (subiektiver Geist); jego antytezą - duch przedmiotowy (objectiver Geist), złożony z tezy prawo, antytezy - etyka indywidualna (Moralität) i syntezy: etyka rodziny oraz syntezy ducha podmiotowego i ducha przedmiotowego, czyli etyki rodziny-etyki społeczeństwa-państwa, czyli najwyższej syntezy: ducha absolutnego (absoluter Geist), który rozpoznany zostaje jako duch w społeczeństwie w państwie. Posiada on także swą „trójkową" dialektykę: sztukę (teza)-religię (antyteza)-filozofię (syntezę).

Dość łatwo zrozumieć i zarazem rozpoznać, że konsekwencją tegoż dialektycznego schematu - bardzo atrakcyjnego intelektualnie ${ }^{54}$ - Hegel spowodował zaprzeczenie jakiejkolwiek możliwości wytłumaczenia świata na sposób mechanicystyczno-deterministyczny (resp. materialistyczno-empiryczny), a jednocześnie podważył i wręcz zanegował sens nauki nowożytnej. Ale niewątpliwie perspektywa, jaką rozwarł swą dialektycznością "trójki" i „trójek" (teza-antyteza-synteza), stanowiła potężną inspirację - i to zapewne nie tylko dla całego współczesnego mu pokolenia myślicieli.

54 Atrakcyjność konstrukcji intelektualnej Hegla dla ówczesnych mu myślicieli pozostaje zrozumiała w sytuacji nowości epoki po rewolucji francuskiej. Dla wykształcającego się na sile państwa pruskiego stanowiła natomiast nadzwyczaj silne uargumentowanie. Na takichże bowiem założeniach, jakie podnieśliśmy przywołując podstawy przekonania ideowego Hegla, nie sposób nie postrzegać i zarazem uważać jednostek [człowieczych] za nieistotne w odniesieniu i porównaniu z Państwem, ucieleśniającym Bóstwo - Bóstwo, którym pozostaje Państwo w każdej fazie swego "wydarzania się", stawania. Państwo zawiera w sobie „substancjalny” Rozum, umiejscowiony w biurokracji - konkretnie: pruskiej, która rozpoznana zostaje przez Hegla jako okazująca się szczytem rozwoju Bóstwa (resp. Boga [niem. Gott]). Jak bardzo pozostawała spójna z duchem germańskim bądź jak bardzo celnie „interpretacja” Hegla wyrażała konkretne przekonania germańskie (teutońskie), można naocznościowo przekonać się, kiedy przywoła się napisy: "Gott mit uns", umiejscowione na pasach munduru Wehrmachtu - aż po II wojnę światową. 
Trudno jednoznacznie ustalać filozoficzny czy historiozoficzny punkt wyjścia naukowo organizowanych refleksji Augusta Cieszkowskiego, lecz przypatrując się kalendarium opublikowanych dzieł, nie sposób nie dostrzec wydanej w 1838 r. publikacji Prolegomena zur Historiosophie i nie wnioskować o podjętej przez niego skutecznej i zarazem pasjonującej - jak się okazało - próbie namysłu nad ówcześnie dominującą problematyką z perspektywy polskiej postawy ideowej. Bowiem zauważamy niemal równolegle wykształcający się namysł Cieszkowskiego nad najbardziej obszerną perspektywą historiozoficzną, która stopniowo była prezentowana polskiemu środowisku naukowemu i czytelniczemu $\mathrm{w}$ sensie elity intelektualnej w noszącym znamienne i jednoznacznie wyraziste zatytułowanie: Ojcze Nasz.

Bezsprzecznie przyszły ówcześnie autor Ojcze Nasz nie mógł się zgodzić z na poły fantastycznym przeprawianiem rzeczywistości, z jakim zapoznał się w filozoficznym opus Hegla. Chodziło o (s)twierdzenie, iż w europejskim kręgu kulturowym należy rozpoznać jedynie dwie dające się rozróżnić kultury: starożytną i średniowieczną - wraz z konsekwentnym postulatem, że należy oczekiwać wykształcenia się kultury - jakby syntezy z obu powyższych, uprzedniejszych. Bezsprzecznie domyślny postulat Heglowy, że kultura nowej epoki będzie się wykształcać na podłożu państwa pruskiego, a w pewnym zakresie - imperatywnie $\mathrm{w}$ totalitaryzmie imperializmu państwa pruskiego (Państwie-Bóstwie), mogła intensywnie wzbudzić i stanowić inspirację do radykalnie innej wizji dziejów, niż postrzegał je autor Fenomenologii ducha, rozpoznając uprzednio podział dziejów na epoki: wschodnią, grecką, rzymską i germańską. Należy bowiem pamiętać o formacji patriotycznej i zarazem katolickiej Cieszkowskiego.

Najpewniej właśnie zakwestionowanie tetrachotomicznego podziału dziejów w rozumieniu Hegla stanowiło dominujący zwrot i podstawę krytyki historiozoficznej wizji Hegla w próbie przeciwstawienia jej przez Cieszkowskiego trychotomicznego podziału tychże dziejów. Autor Ojcze Nasz wyróżnił przeszłość (epoka sztuki - Kunst), teraźniejszość (epoka myśli Wissenschaft), rozpoznawaną od początków chrześcijaństwa, i przyszłość (epoka czynu - Tat), w której dokona się urzeczywistnienie przeznaczenia ludzkości $i^{55}$. Oczywiście, w tymże zakresie pozostajemy zmuszeni uznać, iż

${ }^{55}$ Nie sposób nie dostrzec w tymże koncepcie - czyli idei ludzkości - niewątpliwego wpływu Augusta Comte'a, który postrzegał „ludzkość” w kategoriach bożka (resp. wielkiej istoty grand être). Dopiero współcześnie zdajemy się rozumieć bardziej dojrzale kwestię i to bardziej w kategorii zabobonu intelektualnego w sensie Józefa Innocentego Bocheńskiego OP. Autor Stu zabobonów poddał w wątpliwość zarówno usiłowanie rozumienia terminu w kategorii desygnowania przezeń konkretnego bytu, jak i wszelkie domniemywanie jakoby wykazywania przez „ludzkość” podobnego charakteru, co naród. W odniesieniu do pierwszego zauważa, że ludzkość nie stanowi bytu bądź rzeczy ani nieskończonej, ani świętej (w uproszczeniu) w sensie kultycznym; w stosunku zaś do drugiego - o ile może kulturowo i cywilizacyjnie wykształcić się wspólnota, integrująca się wokół określonego ideału i systematu struktury organizacyj- 
w realiach idei pozytywistycznej epoki autor Ojcze Nasz nie był w stanie uniknąć ideowo-intelektualnych mielizn, z których współcześnie zdajemy sobie sprawę. Stwierdzenie to odnosi się do konceptu ludzkości.

Zanim jednak przejdziemy do ukazania, jak bardzo bliski pozostawał uchwycenia rzeczywistości wydarzania się człowieczego spełniania się w jestestwie - także w głębi wiary kontemplatywnej w Trójjedynego - w realiach glorii życia jako wydarzania się kulturowego społeczeństw - wspólnot i zbiorów podmiotów człowieczych spełniających się w swym jestestwie, świadomie lub nie, rozpoznających siebie podmiotowo bądź pozostających na poziomie wypełniania obowiązku bądź żądzy zmysłowego „doznania” "rozkoszy” siebie, konieczne wydaje się podniesienie kwestii wizji dziejów w kategoriach Ducha Świętego, przedstawionej elicie intelektualnej mediewalnego Christianitas przez Joachima z Fiore ${ }^{56}$ (ok. 1132 lub 1145-ok. 1202). Dopiero po odnowie teologicznej, jaka miała miejsce w pierwszej połowie XX stulecia $^{57}$, możliwe okazało się uchwycenie istoty debaty uniwersyteckiej pomiędzy dwunastowiecznym wizjonerem chrześcijańskim Opatem z Kalabrii a Bonawenturą (ok. 1217-1274), który w imię realizmu wydarzającej się rzeczywistości świata starał się oczyścić z utopii rozumienie chrześcijańskiej eschatologii ${ }^{58}$.

Oczywiście, w powyższej kwestii należy pamiętać o nieustannej powściągliwości katolicyzmu - zwłaszcza w okresie potrydenckim, czyli od nowożytnego Humanizmu i Reformacji. Współcześnie dopiero sobie bowiem uświadomiliśmy przyczynę tego typowo katolickiego deficytu pneumatologicznego. Tym bardziej badawczo należy docenić przedsięwzięcie refleksji i zarazem namysłu nad Wydarzeniem Jezus-Chrystus jako realizmem Słowa objawionego w stworzeniu i zarazem objawiającego się w człowieczych dziejach Słowa zwieńczonego w Wydarzeniu Jezus-Chrystus, które właśnie w takiejże teologicznej koncepcji - i to po odnowie teologicznej w koncepcji teologii jako wiary in statu scientiae, rozpoznajemy jako Pełnia dziejów i czasu, rozcinają-

nej i nadto rozróżniająca się od innych grup czy zbiorowości, a nawet zmagająca się z innymi systematami uorganizowań o zachowanie tegoż ideału swej jedności i wspólnego interesu egzystencjalnego, o tyle „ludzkość” jako podobna grupa nie istnieje (por. J. Bocheński, Sto zabobonów, Kraków 1995, s. 75-76).

56 Gioachino da Fiore, teolog pochodzenia włoskiego, występujący przeciwko teologii trynitarnej Piotra Lombarda, uważając ją za heretycką; jednak jego własne poglądy na Trójcę Świętą zostały potępione (1215) podczas soboru laterańskiego IV. Wraz ze śmiercią da Fiore zyskały wielką popularność jego komentarze apokaliptyczne, w których nawiązując do chiliazmu (resp. millenaryzm), utrzymywał, że dzieje świata dzielą się na trzy części: okres Boga Ojca (Stary Testament), okres Syna Bożego (Nowy Testament) i okres Ducha Świętego (Ewangelia Wieczna), mająca się rozpocząć ok. 1260 r.

57 Zob. D. Kubicki, Le Saulchoir, czyli „wypadek” teologiczny lat czterdziestych XX wieku, „Poznańskie Studia Teologiczne” t. 17, Poznań 2004, s. 125-169; tegoż, Poszukiwania projektu teologii katolickiej opartej na realizmie Słowa objawionego w dziejach, Poznań 2004.

58 Zob. J. Ratzinger, Die Geschichtstheologie des heiligen Bonavetura, Regensburg 1959; wyd. pol. J. Ratzinger, Świętego Bonawentury teologia historii, tłum. I. Zieliński, Lublin 2010. 
ca przeszłość i przyszłość w teraźniejszości spełniania się w jestestwie każdego człowieczego podmiotu ${ }^{59}$.

Przywołajmy jedynie pewien fragment rozważań Cieszkowskiego niezmiernie ważny i zarazem wielce interesujący: „Rozbierając we wstępnej księdze pojęcie Świata i Zaświata pod wyłączną kategorią Czasu, tj. wyobrażeniem życia teraźniejszego i przyszłego, doszliśmy do przekonania, iż największy błąd, jaki tkwił w pojęciu tych stosunków, zależał na fałszywie pojętej sprzeczności między Doczesnością a Wiecznością, które dopóki porównywano do siebie i przeciwstawiono sobie nawzajem, jakoby stanowiły pojęcie równorzędne, nawzajem się wyłączyć mogące, tym samym pojednać nigdy nie umiano, a to z prostej przyczyny, iż sama Wieczność, prawdziwie pojęta, już przez się stanowi wszelkich doczesności pojednanie, ogarnia w siebie wszelkie doczesności, bez których byłaby sama próżnią, że przeto wszelka Doczesność nie w żadnym wyłącznym, lecz we włącznym stosunku do Wieczności być może" $\mathrm{e}^{\prime 0}$.

Nie sposób nie podnieść, że przywołane słowa refleksji Cieszkowskiego przekonują i zarazem unaoczniają, że ich autor dosięgnął wymiar najwyższego i najpełniejszego postrzegania i rozumienia rzeczywistości wraz z człowieczą oikoumene. Ale swą twórczą transformacją idei postrzegania wydarzania się physis rzeczywistości przyczynił się do rozwoju badawczej refleksji nad dziejami, dokonując jednocześnie ukonkretnienia tychże rozważań wprowadzając do niej namysł nad rozwojem doktryn polityczno-społecznych i gospodarczo-ekonomicznych.

W takiejże perspektywie podmiot ludzki nie jest już postrzegany w sensie Hegla jako nic nie znaczące ożywione jestestwo, lecz odnajduje się twórczo pojmowany jako indywiduum osobowe i zarazem jako socjum osobowe. Konsekwentnie twórczy czyn i jakiekolwiek działanie człowieczego podmiotu stający się w zbiorowości aktywnością publiczną i wydarzaniem się zbiorowości okazuje się sposobem istnienia społeczności. Stanowi zarazem o funkcjonalnych cechach podmiotowości społecznej. W takiejże perspektywie właśnie samorządność - wyrastająca z czynu twórczego osoby - uznaje autor Ojcze Nasz za najpierwszy i najbardziej podstawowy warunek podmiotowości publicznej. Dostrzegamy, jak bardzo oddala się Cieszkowski od idealizmu Hegla i jego zinterpretowania „świata cieni” Platona. Właśnie samorządność uznaje autor Wprowadzenia do historiozofii za cechę atrybutywną zbiorowości ludzkich, bez której stan społeczeństwa charakteryzuje nieprzezwyciężalna dysfunkcja, czyli walka, rozerwanie, rozrywanie wspólnotowości i poczucia

${ }^{59}$ Zob. D. Kubicki, Kościót Ducha Świętego jako locus theologicus refleksji nad objawiającym się Słowem w stworzeniu i człowieczych dziejach, zwieńczonym w Wydarzeniu Jezus-Chrystus", [w:] Duch Kościoła - Kościót Ducha. Studia teologii dogmatycznej, t. 2, pod red. A. Proniewskiego, Białystok 2014, s. 122.

${ }^{60}$ A. Cieszkowski, Ojcze Nasz, t. II, Poznań 1899, s. 260. 
wspólności dobra publicznego, interesu wspólnego ${ }^{61}$. Ale równolegle rozpoznaje kategoryczność stosowania wartości konstytuujących dobro wspólne, interes publiczny. Obywatelską postawę rozpoznaje jednocześnie prawem i obowiązkiem każdego wolnego człowieka i każdego sprawiedliwego społeczeństwa. Właśnie takie społeczeństwo rozpoznaje jako stanowiące urzeczywistnienie w rozwoju „ducha ludzkości”. W sumie rozpoznanie wartości społecznych jako walorów "cnoty” i zarazem rozpoznanie zbiorowych realizacji wartości "dobra społecznego” jako urzeczywistnienia świadomości aksjologicznej ludzi pozwalają konsekwentnie Cieszkowskiemu rozpoznać pewną imperatywność świadomości, kiedy ziszcza się w czynie społecznie ludzkim. Właśnie źródło dobra wspólnotowego ludzi i przejaw pozytywności społecznej - aktywność publiczną ludzi - rozpoznaje w kategoriach uzewnętrznienia się 'społeczności ducha”. Tak więc wszelkie działania na rzecz dobra publicznego rozpoznaje za najbardziej istotny wyraz upodmiotowienia ludzi, nie umniejszając jednak warunku skutecznego funkcjonowania wspólnot ludzkich, za który uznaje i rozpoznaje samoogranizację wspólnot, człowieczych oikoumene, czyli ich samorządność.

W tymże rozpoznaniu i zarazem postulacie społecznym dostrzegamy również, jak bardzo - pomimo takiejże samej perspektywy historiozoficznej - różni się i rozróżnił się od Hegla i jego wpływu na ówczesnych sobie myślicieli. W perspektywie historiozoficznej zdołał ująć istotę polskiego systematu społeczno-państwowego: kształtowania się narodu i społeczeństwa oddolnego poprzez samorządność i samoorganizację - tak odmiennego od ducha państwowości germańskiej w jej pruskim systemacie.

Należałoby jedynie jeszcze dopowiedzieć, że niewątpliwą konsekwencją takiego postawienia kwestii narodu i postrzegania jego kulturowego dziedzictwa, czyli samoorganizowania się i samorządności wraz z tworzeniem wytworu kulturowego w spełnianiu się każdego w jestestwie w glorii życia, autor Ojcze Nasz może w pełni rozpoznać dziej narodu jako istotne źródło treści edukacyjnych - treści, które pomagają pokoleniom młodym wiekiem dorastać do postaw obywatelskich. Nie sposób nie stwierdzić, że w takimże rozumieniu człowieczej i obywatelskiej podmiotowości daleki pozostaje modnej w stuleciu rewolucyjnych utopii idei utopijnego gminowładztwa.

Chcielibyśmy zwieńczyć powyższe rozważanie - zapewne wywołującym niedosyt wniknięcia w historiozoficzne i badawcze opus Cieszkowskiego poniższym stwierdzeniem. Bezsprzecznie autor Ojcze Nasz skutecznie rozwarł na oścież perspektywy, które niedostępne były w nowożytnym świecie nie-, Ja". Pozostaje nadzwyczajną tajemnicą, jak w tak długim życiu twórczym, przepełnionym nieustanną aktywnością - życiu, bogatym w wejrzenia

${ }^{61}$ Por. K. Wojnowski, Wstęp. August hr. Cieszkowski, s. 21. 
w wydarzanie się zachodnioeuropejskich oikoumene, różniących się niepowtarzalnością kulturową i odcieniem cywilizacyjności wspólnego matecznika, kształtowała się oryginalna umysłowość autora Prolegomeny do historiozofii. Pozostaje oczywistym, że podstawę tejże umysłowości wyznaczała myśl filozoficzna - namysł nad wydarzającą się rzeczywistością wspólnot kulturowych i cywilizacyjnych systematów różnorodnych państwowości z jednoczesnym jego odnoszeniem do Wydarzenia Jezus-Chrystus (w uproszczeniu) jako Pełni czasu.

I chociaż doczekaliśmy się do chwili obecnej olbrzymiej ilości studiów i rozważań mających za przedmiot poszczególne opus Cieszkowskiego i oczekujemy na pełną jego biografię naukową, to jednak powyższa refleksja, ukazując niezwykłość intuicji badawczych autora Ojcze Nasz. W kontekście swej ówczesności i jej sytuacji duchowej przekona do bardziej pogłębionych badań nad fenomenem polskiej kulturowości i cywilizacyjności, których twórczym podmiotem był August hr. Cieszkowski.

ks. Dominik Kubicki

$$
\begin{gathered}
\text { Myśl historiozoficzna Augusta Cieszkowskiego } \\
\text { Stulecie niebywałych przemian polityczno-społecznych } \\
\text { impulsem interdyscyplinarnych zainteresowań autora } \\
\text { Prolegomeny do historiozofii }
\end{gathered}
$$

\begin{abstract}
Streszczenie
Autor prezentuje imponującą spuściznę pisarską wraz z nakreśleniem działalności naukowo-organizacyjnej, politycznej, społeczno-kulturowej i ekonomiczno-gospodarczej Augusta hr. Cieszkowskiego (1814-1894). Ujmuje ją w kontekście niebywałych przemian polityczno-społecznych XIX stulecia. Rozpoznaje je jako impuls interdyscyplinarnych zainteresowań autora Prolegomeny do historiozofii.
\end{abstract}

The Historiosophical Though of August Cieszkowski. A hundred years of incredible political and social transformations - a stimulus for his interdisciplinary interests

\footnotetext{
Abstract

The author presents an impressive literature heritage of count August Cieszkowski (1814-1894), emphasizing his scientific, organizational, political, social, cultural and economic activity. It is shown within the frame of unbelievable political and social transformations that occurred in the 19th century. The author identifies these as a stimulus of interdisciplinary interests of the author of "Prolegomena do historiozofii".
} 